\title{
Effect of corn straw manure as dairy manure on productivity and profitability of wheat at Huang- Huai-Hai plain
}

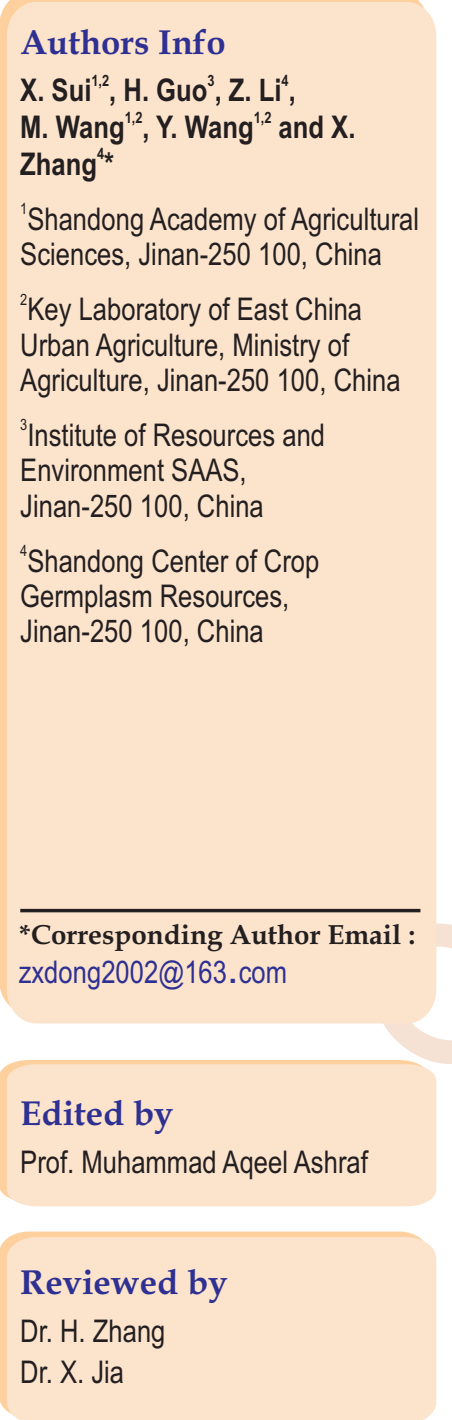

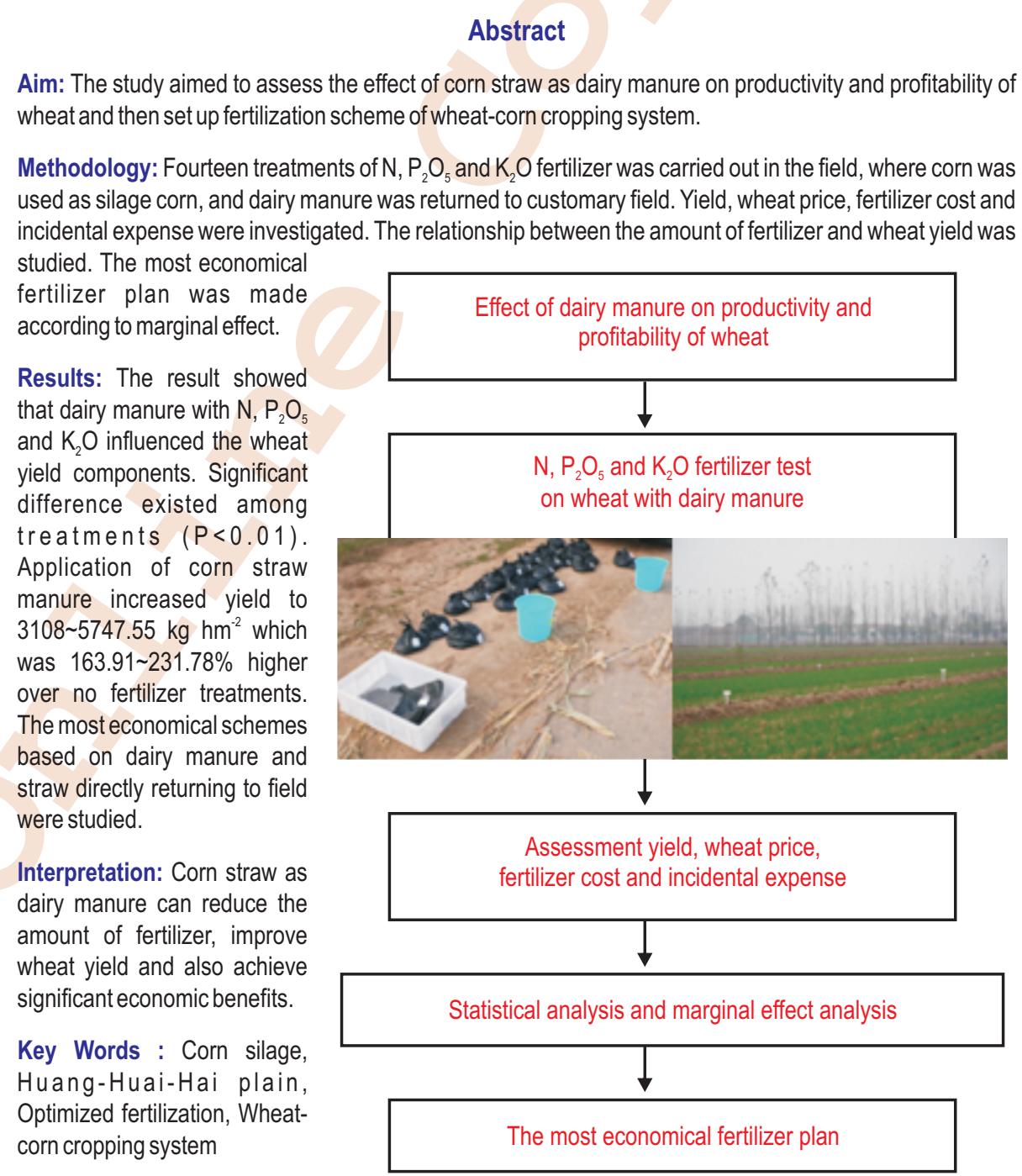

Citation: Sui, X. , H. Guo, Z. Li, M. Wang, Y. Wang and X. Zhang: Effect of corn straw manure as dairy manure on productivity and profitability of wheat at Huang-HuaiHai plain. J. Environ. Biol., 40,441-447 (2019) 


\section{Introduction}

Huang-Huai-Hai plain, also known as North China plain is China's largest landscape unit located between $113^{\circ} \mathrm{E}$ to east coastline, and between $32^{\circ} 002 \mathrm{~N}$ to $40^{\circ} 302 \mathrm{~N}$. It's administrative scope mainly involves 5 provinces (Hebei, Henan, Shandong, Anhui and Jiangsu) and 2 cities (Beijing and Tianjin), and also there are 311 county units (Shuman et al., 2014; Azizan et al., 2017). Huang-Huai-Hai plain is China's major grain producing area. Wheat-corn is the most important cropping system at Huang-Huai-Hai plain. This plain produces about $70 \%$ of wheat, and $30 \%$ corn in China, which produces $0.8855 \times 10^{8}$ tons wheat straw and $1.1505 \times 10^{8}$ tons corn straw (National Bureau of Statistic of China, 2011; Abd Samad et al., 2017; Ayaz et al., 2018).

Straw is agricultural waste and was used in place firewood in the past. With the emergence of new energy, straw is being piled up and even set on fire leading to serious environmental pollution (Feiyue and Jianfei, 2013; Wei et al., 2011; Hong et al., 2008; Lu et al., 2018). China's Eleventh Five Plan introduced circular agriculture monographic study, and the achievement of the study diversified ways to deal with straw such as directly returning to field, using as edible matrix, silage and pellet fuel, etc. Agricultural industry chain extended with higher output (Kejun et al., 2012; Zhigang et al., 2010; Guoqin, 1997; Qiang et al., 2011). And agricultural environmental pollution improved. Nutrient released and soil microbial biomass was increased as crop straws manure. (Xuecai et al., 2004; Sihai et al., 2011; Ismail and Hanafiah, 2017; Gu and Zhang, 2018).

At the same time, in order to improve resident's quality of life, Premier Wen Jiabao proposed "to carry out milk industry revitalization plan". Corn straw silage effectively alleviated the contradiction between grain and feed (Lizhen et al., 2006; Hassan et al., 2017). Corn straw manure can improve soil structure and nutrient content (Xiaobin et al., 2000; Halim et al., 2017; Kassim, et al., 2018). In dairy farming areas, farmer can gain free manure after selling corn straw as silage. In view of the above, this study aimed to set up fertilization scheme of wheat-corn cropping system, where corn was used as silage corn, and the dairy manure was returned to customary field.

\section{Materials and Methods}

Study area: This study was carried out at Dezhou City, Shandong Province, Zhanghua Town. The soil of study area is sandy loam, with organic matter $16.2 \mathrm{~g} \mathrm{~kg}^{-1}$ alkali solution nitrogen $56.6 \mathrm{mg} \mathrm{kg}^{-1}$ available phosphorus $29.4 \mathrm{mg} \mathrm{kg}^{-1}$ and available potassium 55.3 $\mathrm{mg} \mathrm{kg}^{-1}$. Wheat Jimai 22 was used in the test. Urea (46-0-0), superphosphate $(0-12-0)$ and potassium sulphate $(0-0-51)$ were used as $\mathrm{N}, \mathrm{P}_{2} \mathrm{O}_{5}$, and $\mathrm{K}_{2} \mathrm{O}$ supplement.

Experimental set up: The study used"3414" field trial design, which involved $\mathrm{N}, \mathrm{P}_{2} \mathrm{O}_{5}, \mathrm{~K}_{2} \mathrm{O} 3$ factors, each factor concerned 4 levels, and there were altogether 14 treatments. As shown in Table 1, the 4 levels contented 0 level, 1 level, 2 level and 3 level. 0 level represented not using fertilizer. 2 level represented the optimum fertilizer. 1 level represented half of the optimum fertilizer. 3 level represented 1.5 times as the optimum fertilizer. The 14 treatments were $\mathrm{N}_{0} \mathrm{P}_{0} \mathrm{~K}_{0}, \mathrm{~N}_{0} \mathrm{P}_{2} \mathrm{~K}_{2}, \mathrm{~N}_{1} \mathrm{P}_{2} \mathrm{~K}_{2}, \mathrm{~N}_{2} \mathrm{P}_{0} \mathrm{~K}_{2}, \mathrm{~N}_{2} \mathrm{P}_{1} \mathrm{~K}_{2}$, $\mathrm{N}_{2} \mathrm{P}_{2} \mathrm{~K}_{2}, \mathrm{~N}_{2} \mathrm{P}_{3} \mathrm{~K}_{2}, \mathrm{~N}_{2} \mathrm{P}_{2} \mathrm{~K}_{0}, \mathrm{~N}_{2} \mathrm{P}_{2} \mathrm{~K}_{1}, \mathrm{~N}_{2} \mathrm{P}_{2} \mathrm{~K}_{3}, \mathrm{~N}_{3} \mathrm{P}_{2} \mathrm{~K}_{2}, \mathrm{~N}_{1} \mathrm{P}_{1} \mathrm{~K}_{2}, \mathrm{~N}_{1} \mathrm{P}_{2} \mathrm{~K}_{1}$, $\mathrm{N}_{2} \mathrm{P}_{1} \mathrm{~K}_{1}$, which were shown in Table 2 . The study had three repeats and random permutation. Wheat was sown by combined seeder. The seeder was set to seeding rate of $25 \mathrm{~kg}_{667 \mathrm{~m}^{-2}}$, row spacing $22-25 \mathrm{~cm}$, and sowing depth $3-5 \mathrm{~cm}$. Fertilizers were mixed and loaded on the seeder. Fertilizers were buried underneath wheat seeds. Urea was applied in half amount while seeding and the rest when dressing. The whole calcium superphosphate and potassium sulfate was all used when seeding. The seeder had compacting device. There were 4 irrigations: after seeding, before over winter, jointing, and flowering with amount of irrigation water were $600 \mathrm{~m}^{3} \mathrm{hm}^{-2}, 600 \mathrm{~m}^{3} \mathrm{hm}^{-2}, 900 \mathrm{~m}^{3} \mathrm{hm}^{-2}, 900 \mathrm{~m}^{3} \mathrm{hm}^{-2}$. Except for fertilizer application, standard agronomic practices were followed for all other field activities.

Dairy manure was provided by Wang Xiang Dairy Farming Cooperative. There will be $45 \mathrm{~m}^{3}$ dairy manure when onehectare corn straw being used as silage. The study took all $45 \mathrm{~m}^{3}$ dairy manure as base fertilizer and researched on the best manure amount, rate of $\mathrm{N}, \mathrm{P}_{2} \mathrm{O}_{5}$ and $\mathrm{K}_{2} \mathrm{O}$. Chemical analysis was carried out, $\mathrm{N}, \mathrm{P}_{2} \mathrm{O}_{5}$ and $\mathrm{K}_{2} \mathrm{O}$ weigh $48 \mathrm{~kg}, 37.5 \mathrm{~kg}$ and $24 \mathrm{~kg}$ for $45 \mathrm{~m}^{3}$ separately (Shidan, B., et al., 2000; Rehman et al., 2017). Based on the level of "the fertilizer effect test of returning straw back to field directly" (Xiaodong, et al., 2016; Chuanlei et al., 2018), this test set 3 nutrient elements' levels as deducting the amount of dairy manure providing for the field. At corn harvest, yield monitor was taken by 5 -point sampling method with each point $1 \mathrm{~m}^{2}$. The main indexes included ear number per unit, grain number per ear, and then calculated yield with those indexes (Weixing et al., 2011; Fahim and Sathi, 2018).

Related data calculation method: Wheat price was $2.52 \mathrm{RMB}$ $\mathrm{kg}^{-1}$. N price was $3.61 \mathrm{RMB} \mathrm{kg}{ }^{-1}$. $\mathrm{P}_{2} \mathrm{O}_{5}$ price was $5.25 \mathrm{RMB} \mathrm{kg}^{-1}$. $\mathrm{K}_{2} \mathrm{O}$ price was $4.35 \mathrm{RMB} \mathrm{kg}^{-1}$. Incidental expense was $1740 \mathrm{RMB}$ $\mathrm{hm}^{-2}$. The average of three repeats in two years' was calculated as treatment result. Incidental expense included the cost on agricultural machinery, pesticides and irrigation.

$$
\text { Wheat output value }=\text { Wheat yield } \times \text { Unit price } \text {. }
$$

Net profit $=$ Output value-Fertilizer cost-Incidental expenses.

\section{Results and Discussion}

As shown in Table 3, N, $\mathrm{P}_{2} \mathrm{O}_{5}$ and $\mathrm{K}_{2} \mathrm{O}$ treatment under corn manure affected ear number per hectare and grain number per ear and yield. The different between treatments were 
Table 1: Factors and levels of fertilizer test for wheat with dairy manure

\begin{tabular}{|c|c|c|c|c|c|}
\hline Factor & Level & $0\left(\mathrm{~kg} \mathrm{hm}^{-2}\right)$ & $1\left(\mathrm{~kg} \mathrm{hm}^{-2}\right)$ & $2\left(\mathrm{~kg} \mathrm{hm}^{-2}\right)$ & $3\left(\mathrm{~kg} \mathrm{hm}^{-2}\right)$ \\
\hline$N$ & & 0 & 55.5 & 157.5 & 261 \\
\hline $\mathrm{P}_{2} \mathrm{O}_{5}$ & & 0 & 24 & 87 & 148.5 \\
\hline $\mathrm{K}_{2} \mathrm{O}$ & & 0 & 43.5 & 111 & 180 \\
\hline
\end{tabular}

Table 2: Fertilizer test's Treatments for Wheat with dairy manure

\begin{tabular}{|c|c|c|c|c|}
\hline No. & Treatment & N Level & $\mathrm{P}_{2} \mathrm{O}_{5}$ Level & $\mathrm{K}_{2} \mathrm{O}$ Level \\
\hline $\mathrm{T} 1$ & $\mathrm{~N}_{0} \mathrm{P}_{0} \mathrm{~K}_{0}$ & 0 & 0 & 0 \\
\hline $\mathrm{T} 2$ & $\mathrm{~N}_{0} \mathrm{P}_{2} \mathrm{~K}_{2}$ & 0 & 2 & 2 \\
\hline T3 & $\mathrm{N}_{1} \mathrm{P}_{2} \mathrm{~K}_{2}$ & 1 & 2 & 2 \\
\hline T4 & $\mathrm{N}_{2} \mathrm{P}_{0} \mathrm{~K}_{2}$ & 2 & 0 & 2 \\
\hline T5 & $\mathrm{N}_{2} \mathrm{P}_{1} \mathrm{~K}_{2}$ & 2 & 1 & 2 \\
\hline T6 & $\mathrm{N}_{2} \mathrm{P}_{2} \mathrm{~K}_{2}$ & 2 & 2 & 2 \\
\hline $\mathrm{T7}$ & $\mathrm{N}_{2} \mathrm{P}_{3} \mathrm{~K}_{2}$ & 2 & 3 & 2 \\
\hline T8 & $\mathrm{N}_{2} \mathrm{P}_{2} \mathrm{~K}_{0}$ & 2 & 2 & 0 \\
\hline T9 & $\mathrm{N}_{2} \mathrm{P}_{2} \mathrm{~K}_{1}$ & 2 & 2 & 1 \\
\hline T10 & $\mathrm{N}_{2} \mathrm{P}_{2} \mathrm{~K}_{3}$ & 2 & 2 & 3 \\
\hline T11 & $\mathrm{N}_{3} \mathrm{P}_{2} \mathrm{~K}_{2}$ & 3 & 2 & 2 \\
\hline T12 & $\mathrm{N}_{1} \mathrm{P}_{1} \mathrm{~K}_{2}$ & 1 & 1 & 2 \\
\hline T13 & $\mathrm{N}_{1} \mathrm{P}_{2} \mathrm{~K}_{1}$ & 1 & 2 & 1 \\
\hline T14 & $\mathrm{N}_{2} \mathrm{P}_{1} \mathrm{~K}_{1}$ & 2 & 1 & 1 \\
\hline
\end{tabular}

Table 3 : Effect of treatments on yield attributes, yield and economics of wheat

\begin{tabular}{|c|c|c|c|c|c|c|c|c|c|c|c|}
\hline No. & Treatment & $\begin{array}{l}\text { Ear number } \\
\text { per unit } \\
\left(10^{4} \mathrm{hm}^{-2}\right)\end{array}$ & & $\begin{array}{l}\text { Grain } \\
\text { number } \\
\text { per ear }\end{array}$ & & $\begin{array}{l}\text { Yield } \\
\left(\mathrm{kg} \mathrm{hm}^{-2}\right)\end{array}$ & & $\begin{array}{l}\text { Yield grow } \\
\text { amount } \\
\left(\mathrm{kg} \mathrm{hm}^{-2}\right)\end{array}$ & $\begin{array}{l}\text { Yield grow } \\
\text { rate }(\%)\end{array}$ & $\begin{array}{l}\text { Output } \\
\text { value } \\
\left(\mathrm{RMB} \mathrm{hm}^{-2}\right)\end{array}$ & $\begin{array}{l}\text { Net income } \\
\left(\text { RMB hm }^{-2}\right)\end{array}$ \\
\hline $\mathrm{T} 1$ & $\mathrm{~N}_{0} \mathrm{P}_{0} \mathrm{~K}_{0}$ & 498.69 & $\mathrm{~J}$ & 13.93 & $G$ & 2480.00 & $\mathrm{~F}$ & - & - & 6249.60 & 4509.60 \\
\hline T2 & $\mathrm{N}_{0} \mathrm{P}_{2} \mathrm{~K}_{2}$ & 540.03 & I & 34.23 & $C D$ & 6599.83 & $E$ & 4119.30 & 166.12 & 16631.58 & 13951.98 \\
\hline T3 & $\mathrm{N}_{1} \mathrm{P}_{2} \mathrm{~K}_{2}$ & 558.69 & $\mathrm{H}$ & 38.17 & A & 7612.49 & $\mathrm{BC}$ & 5131.95 & 206.96 & 19183.48 & 16303.53 \\
\hline T4 & $\mathrm{N}_{2} \mathrm{P}_{0} \mathrm{~K}_{2}$ & 576.70 & G & 36.55 & B & 7524.92 & C & 5044.35 & 203.42 & 18962.81 & 16171.39 \\
\hline T5 & $\mathrm{N}_{2} \mathrm{P}_{1} \mathrm{~K}_{2}^{2}$ & 566.70 & $\mathrm{GH}$ & 36.95 & $A B$ & 7475.36 & C & 4994.85 & 201.43 & 18837.90 & 15920.48 \\
\hline T6 & $\mathrm{N}_{2} \mathrm{P}_{2} \mathrm{~K}_{2}$ & 649.37 & $B C$ & 28.97 & $F$ & 6715.16 & $\mathrm{DE}$ & 4234.65 & 170.77 & 16922.19 & 13674.02 \\
\hline $\mathrm{T} 7$ & $\mathrm{~N}_{2} \mathrm{P}_{3} \mathrm{~K}_{2}$ & 597.36 & $\mathrm{~F}$ & 36.35 & B & 7751.95 & $\mathrm{BC}$ & 5271.45 & 212.58 & 19534.92 & 15963.87 \\
\hline T8 & $\mathrm{N}_{2} \mathrm{P}_{2} \mathrm{~K}_{0}$ & 554.69 & $\mathrm{H}$ & 35.40 & $\mathrm{BC}$ & 7010.12 & D & 4529.55 & 182.67 & 17665.49 & 14900.17 \\
\hline T9 & $\mathrm{N}_{2} \mathrm{P}_{2} \mathrm{~K}_{1}$ & 646.03 & C & 33.60 & $D$ & 7749.29 & $\mathrm{BC}$ & 5268.75 & 212.47 & 19528.20 & 16573.65 \\
\hline $\mathrm{T} 10$ & $\mathrm{~N}_{2} \mathrm{P}_{2} \mathrm{~K}_{3}$ & 689.37 & A & 33.43 & D & 8228.09 & A & 5747.55 & 231.78 & 20734.78 & 17186.45 \\
\hline $\mathrm{T} 11$ & $\mathrm{~N}_{3} \mathrm{P}_{2} \mathrm{~K}_{2}$ & 619.36 & DE & 31.00 & $E$ & 6854.50 & $\mathrm{DE}$ & 4374.00 & 176.39 & 17273.35 & 13651.54 \\
\hline T12 & $\mathrm{N}_{1} \mathrm{P}_{1} \mathrm{~K}_{2}$ & 614.03 & $E$ & 35.77 & $\mathrm{BC}$ & 7840.37 & $\mathrm{BC}$ & 5359.80 & 216.14 & 19757.74 & 17208.54 \\
\hline T13 & $\mathrm{N}_{1} \mathrm{P}_{2} \mathrm{~K}_{1}$ & 661.37 & B & 33.77 & $D$ & 7972.57 & $A B$ & 5491.95 & 221.47 & 20090.89 & 17504.56 \\
\hline T14 & $\mathrm{N}_{2} \mathrm{P}_{1} \mathrm{~K}_{1}$ & 630.00 & D & 29.10 & $\mathrm{~F}$ & 6544.88 & $E$ & 3108.90 & 163.91 & 16493.10 & 13869.30 \\
\hline
\end{tabular}

Remark: $A, B, C, D, E, F, G, H, I$ were the results of one-way Anova, which were very significant difference $(P<0.01)$

significant. The ear number per hectare, grain number per ear and yield was lowest in $\mathrm{N}_{0} \mathrm{P}_{0} \mathrm{~K}_{0}$ treatment. The ear number per hectare and the yield were highest with $\mathrm{N}_{2} \mathrm{P}_{2} \mathrm{~K}_{3}$. The grain number per ear was highest in case of $\mathrm{N}_{1} \mathrm{P}_{2} \mathrm{~K}_{2}$ treatment. Application of corn manure along with additional fertilizer resulted $3108 \sim 5747.55 \mathrm{~kg}$ $\mathrm{hm}^{-2}$ wheat yield which was higher than sole corn manure application. Compared with $\mathrm{N}_{0} \mathrm{P}_{0} \mathrm{~K}_{0}$ treatment, yield increasing rate reached within the range of $163.91 \% \sim 231.78 \%$. All the treatments input and output were calculated, the net profit for the treatment $\mathrm{N}_{1} \mathrm{P}_{2} \mathrm{~K}_{1}$ was highest.

The relationship between wheat yield and the amount of nitrogen, phosphorus and potassium was significant. Linear model, exponential model and one-place quadratic model were set up between applied nutrients $\left(\mathrm{N}_{2} \mathrm{P}_{2} \mathrm{O}_{5}\right.$ and $\left.\mathrm{K}_{2} \mathrm{O}\right)$ and yield obtained. Among the three kinds of models, one-place quadratic 

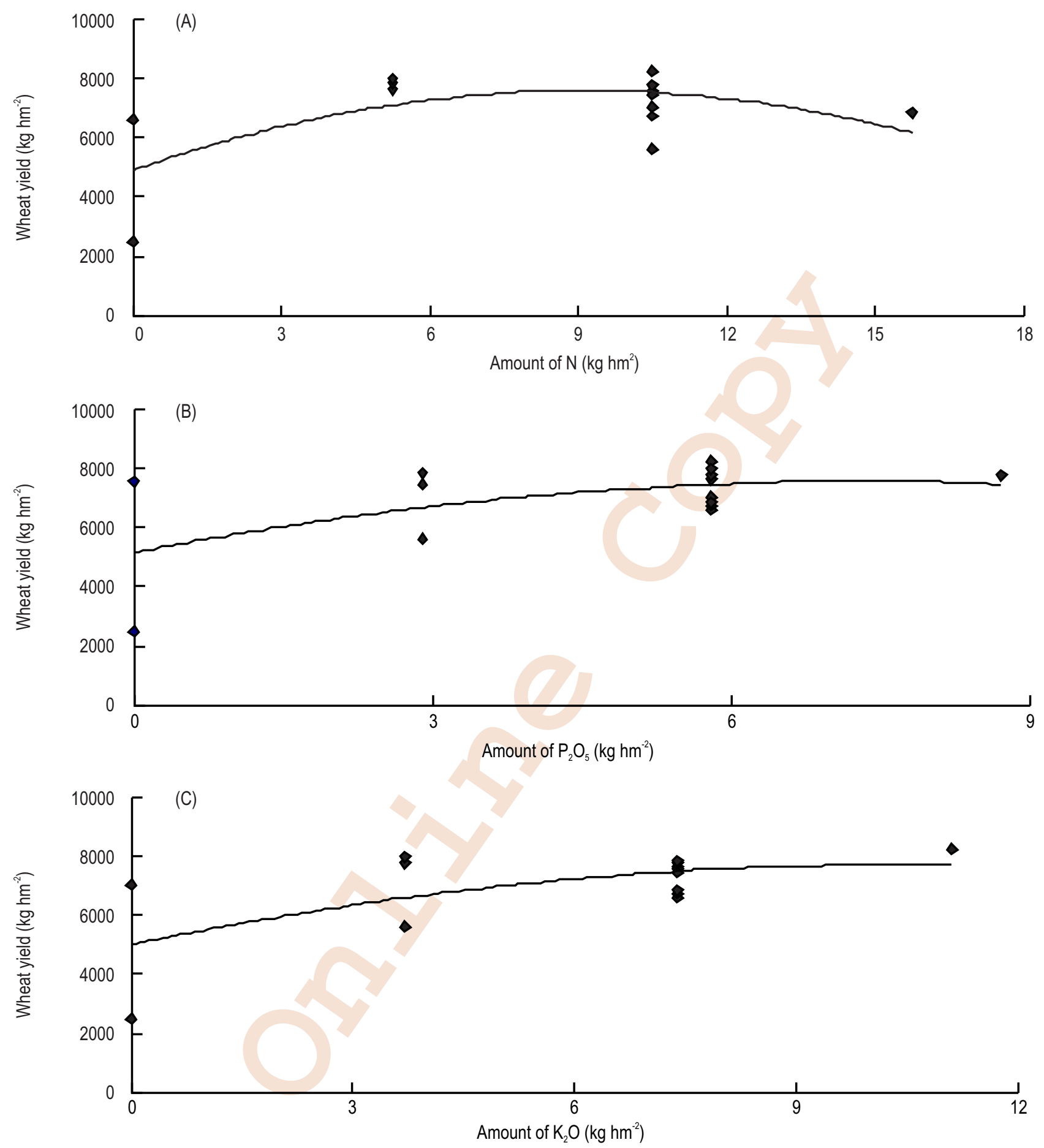

Fig. 1 : Yield quadratic regression model with $(A) \mathrm{N}$; $(B) \mathrm{P}_{2} \mathrm{O}_{5}$ and $(C) \mathrm{K}_{2} \mathrm{O}$.

model is the best one. The best models are shown in Table 4. As shown in Fig.1 to Fig.3, wheat yield grows at first and then gets down with the increasing amount of nutrients which fits he law of diminishing returns.

In order to consider interactive effects among $\mathrm{N}, \mathrm{P}_{2} \mathrm{O}_{5}$, and $\mathrm{K}_{2} \mathrm{O}$, the ternary quadratic regression models of wheat yield and three kinds of fertilizer were also set up. Which was used SPSS (Statistic Package for Social Science) regression analysis function.

$$
Y=2507.79-69.99 \mathrm{~N}-15.26 \mathrm{~N}^{2}+1034.95\left(\mathrm{P}_{2} \mathrm{O}_{5}\right)+4.69
$$


Table 4 : Wheat yield regression models with $\mathrm{N}, \mathrm{P}_{2} \mathrm{O}_{5}$ and $\mathrm{K}_{2} \mathrm{O}$

\begin{tabular}{llll}
\hline Independent variable & Model type & Models & Goodness of Fit R $^{2}$ \\
\hline $\mathrm{N}$ & linear model & $\mathrm{y}=141.68 \mathrm{x}+5788.6$ & 0.1875 \\
& exponential model & $\mathrm{y}=5147.6 \mathrm{e}^{0.035 \mathrm{x}}$ & 0.2277 \\
& one-place quadratic model & $\mathrm{y}=-32.48 \mathrm{x}^{2}+591.24 \mathrm{x}+4893.4$ & $0.4233^{* *}$ \\
$\mathrm{P}_{2} \mathrm{O}_{5}$ & linear model & $\mathrm{y}=313.82 \mathrm{x}+5527.4$ & $0.2807^{*}$ \\
& exponential model & $\mathrm{y}=4950.7 \mathrm{e}^{0.0674 x}$ & $0.2988^{*}$ \\
$\mathrm{~K}_{2} \mathrm{O}$ & one-place quadratic model & $\mathrm{y}=-45.193 \mathrm{x}^{2}+659.34 \mathrm{x}+5147.3$ & $0.3232^{*}$ \\
& linear model & $\mathrm{y}=277.49 \mathrm{x}+5344.1$ & $0.3573^{*}$ \\
& exponential model & $\mathrm{y}=4829.6 \mathrm{e}^{0.0571}$ & $0.3490^{*}$ \\
& one-place quadratic model & $\mathrm{y}=-24.884 \mathrm{x}^{2}+520.22 \mathrm{x}+5003.4$ & $0.3914^{* *}$ \\
\hline
\end{tabular}

Remark: "showed the difference was significant $(\mathrm{p}<0.05)$, and "showed the difference was extremely significant $(\mathrm{p}<0.01)$

Table 5 : Acomparison between the highest wheat yield fertilizer program and the most economical fertilizer program

\begin{tabular}{lllllll}
\hline Fertilizer program & $\mathbf{N}\left(\mathrm{kg} \mathrm{hm}^{-2}\right)$ & $\mathrm{P}_{2} \mathrm{O}_{5}\left(\mathrm{~kg} \mathrm{hm}^{-2}\right)$ & $\mathrm{K}_{2} \mathrm{O}\left(\mathrm{kg} \mathrm{hm}^{-2}\right)$ & Yield $\left(\mathrm{kg} \mathrm{hm}^{-2}\right)$ & $\begin{array}{l}\text { Output value } \\
(\mathrm{RMB} \mathrm{hm}\end{array}$ & $\begin{array}{l}\text { Net profit } \\
\left(\mathrm{RMB} \mathrm{hm}^{-2}\right)\end{array}$ \\
\hline The highest yield fertilizer program & 121.24 & 88.92 & 110.38 & 7659.28 & 19301.39 & 9902.11 \\
The most economical fertilizer program & 102.59 & 82.77 & 105.43 & 7635.24 & 19240.80 & 9865.56 \\
The difference value & -18.65 & -6.15 & -4.95 & -24.04 & -60.58 & 490.92 \\
\hline
\end{tabular}

Remark: The difference value $=$ The most economical fertilizer program - The highest yield fertilizer program

Table 6 : Acomparison of the most economical fertilizer on wheat between corn straw directly to field and straw dairy manure

\begin{tabular}{llcl}
\hline Pattern & \multicolumn{2}{c}{ The most economical fertilizer program } \\
\cline { 2 - 4 } & $\mathrm{N}\left(\mathbf{k g ~ h m}^{-2}\right)$ & $\mathbf{P}_{2} \mathbf{O}_{5}\left(\mathbf{k g ~ h m}^{-2}\right)$ & $\mathrm{K}_{2} \mathbf{O}\left(\mathbf{k g ~ h m}^{-2}\right)$ \\
\hline Corn straw being directly returned to field & & & 135.00 \\
(Xiaodong, ,etal., 2016) & 210.00 & 120.00 & 105.43 \\
Corn straw dairy manure & 102.59 & 82.77 & -29.57 \\
The difference value of the two patterns & -107.41 & -37.23 & -21.90 \\
The proportion of the difference value to the & -51.15 & -31.03 & 24 \\
pattern corn straw being directly returned to field & & 37.5 & 24 \\
The providing fertilizer amount of corn straw dairy manure & 48 &
\end{tabular}

Remark: The difference value of the two patterns = the most economical fertilizer program of corn straw being directly returned to field - The highest yield fertilizer program of corn straw dairy manure; The proportion of the difference value to the pattern corn straw being directly returned to field= The difference value of the two patterns / Corn straw being directly returned to field

$\left(\mathrm{P}_{2} \mathrm{O}_{5}\right)^{2}+643.32\left(\mathrm{~K}_{2} \mathrm{O}\right)+6.20\left(\mathrm{~K}_{2} \mathrm{O}\right)^{2}+15.65 \mathrm{~N}\left(\mathrm{P}_{2} \mathrm{O}_{5}\right)+30.42 \mathrm{~N}$ $\left(\mathrm{K}_{2} \mathrm{O}\right)-165.40\left(\mathrm{P}_{2} \mathrm{O}_{5}\right)\left(\mathrm{K}_{2} \mathrm{O}\right)\left(\mathrm{n}=9, \mathrm{R}^{2}=0.96^{* *}\right)$

Based on the model, when marginal revenue and $\mathrm{N}$, $\mathrm{P}_{2} \mathrm{O}_{5}$ and $\mathrm{K}_{2} \mathrm{O}$ were zero, highest yield of wheat was obtained. Highest yield of wheat $\left(7659.28 \mathrm{~kg} \mathrm{hm}^{-2}\right)$ was obtained when $121.24 \mathrm{~kg} \mathrm{hm}^{-2} \mathrm{~N}, 88.92 \mathrm{~kg} \mathrm{hm}^{-2} \mathrm{P}_{2} \mathrm{O}_{5}$, and $110.38 \mathrm{~kg} \mathrm{hm}^{-2} \mathrm{~K}_{2} \mathrm{O}$ was used.

Based on the model, the optimum economic fertilization for wheat was obtained when marginal revenue of fertilization cost equal to the output value. The economic optimal rates of nitrogen, phosphorus and potassium fertilization is $102.59,82.77$ and $105.43 \mathrm{~kg} \mathrm{hm}^{-2}$, respectively, which leads to a significant increase in grain yield. Compare to the fertilization program of highest yield, the optimum economic fertilization program can save $18.65 \mathrm{~kg} \mathrm{hm}^{-2} \mathrm{~N}, 6.15 \mathrm{~kg} \mathrm{hm}^{-2} \mathrm{P}_{2} \mathrm{O}_{5}$ and $4.95 \mathrm{~kg} \mathrm{hm}^{-2} \mathrm{~K}$, respectively, when wheat grain yield reduced $60.58 \mathrm{~kg} \mathrm{hm}^{-2}$. While the net profit increased 490.92 $\mathrm{RMB} \mathrm{hm}^{-2}$ (table 5).

The most optimum economic nitrogen, phosphorus and potassium fertilization with retention of corn straw was lower than that those values under directresidues retention (table 5). Nitrogen, phosphorus and potassium fertilizaion decreased by $51.15,31.03$ and $29.57 \%$, respectively. Specifically, the reduction of nitrogen (107.41 kg hm-2) is much higher than that value with addition of cow dung (48 $\mathrm{kg} \mathrm{hm}-2$ ), followed by potassium, and phosphorus had insignificant change. 
Wheat fertilizer can save consumption under the condition of corn straw being returned back to field by dairy manure as organic fertilizer, which experienced composting fermentation, then that under corn straw being returned back to field directly. The saved consumption contains $107.41 \mathrm{~kg} \mathrm{hm}^{-2} \mathrm{~N}$, $37.23 \mathrm{~kg} \mathrm{hm}^{-2} \mathrm{P}_{2} \mathrm{O}_{5}, 29.57 \mathrm{~kg} \mathrm{hm}^{-2} \mathrm{~K}_{2} \mathrm{O}$. Corn straw being returned back to field by dairy manure in situ field can provide $48 \mathrm{~kg} \mathrm{hm}^{-2} \mathrm{~N}$, $37.5 \mathrm{~kg} \mathrm{hm}^{-2} \mathrm{P}_{2} \mathrm{O}_{5}$, and $24 \mathrm{~kg} \mathrm{hm}^{-2} \mathrm{~K}_{2} \mathrm{O}$. In addition to the amount dairy manure providing fertilizer, corn straw being returned back to field by dairy manure can save $59.41 \mathrm{~kg} \mathrm{hm}^{-2} \mathrm{~N}, 5.57 \mathrm{~kg} \mathrm{hm}^{-2}$ $\mathrm{K}_{2} \mathrm{O}$. The efficiency of dairy manure is much higher than that of chemical fertilizer. Nitrogen is required by both corn straw decomposition and wheat growth. There is a huge competition (Cuiping et al., 2011; Hanafiah et al., 2017). Dairy manure can provide wheat growth with nitrogen directly and promote the transformation of potassium forms in fertilizers and soils. This is consistent with Zhang Ming's research results, that is, dairy manure combined with chemical fertilizer can significantly improve the utilization rate of nitrogen and potassium fertilizer, but the improvement effect of phosphorus fertilizer utilization rate is not significant.(Ming et al., 2014; Elsayed, 2017; Biswas, 2018).

The study recommends the most economical wheat fertilizer; $102.59 \mathrm{~kg} \mathrm{hm}^{-2} \mathrm{~N}, 82.77 \mathrm{~kg} \mathrm{hm}^{-2} \mathrm{P}_{2} \mathrm{O}_{5}$, and $105.43 \mathrm{~kg} \mathrm{hm}^{-2}$ $\mathrm{K}_{2} \mathrm{O}$ in the field when corn straw is returned back by dairy manure in situ. Breaking straw costs a lot of fuel power when returned back to field directly. In order to reduce the cost, a large number of agricultural machinery drivers couldn't break straw fully with low fragmentation degree, which influenced wheat sowing and emergence (Shaokun et al., 2006). While the commercial organic fertilizer by dairy manure can improve soil structure and supply wheat with nutrients, with no influence on wheat sowing and emergence.

\section{Acknowledgments}

This paper belongs to the project of the "National Scientific and Technological Support Plan", No.2012BAD14B07; Technology Integration and Demonstration of Recycling Utilization of Straw Resources in Huang-Huai-Hai Plain.

\section{References}

Abd Samad, N.S., A. Amid, D.N. Jimat and N.A.A. Shukor: Isolation and identification of halophilic bacteria producing halotolerant protease. Sci. Herit. J., 1, 07-09(2017).

Ayaz, T., A.M. Khattak and N. Ahmad: Supra soft R-separation axioms. Acta Sci. Malays., 2, 27-31 (2018).

Azizan, N.H., Z.A.Z. Abidin and I.C. Phang: Study of cucumber mosaic virus gene expression in Capsicum annuum. Sci. Herit. J., 1, 2931(2017).

Biswas, J.K.: A few words on black rice. Malays. J. Halal Res., 1, 01-02 (2018).

Chuanlei, L., L. Guomin, H. Yuanfei and W. Guojun: Research on mental health status and the relationship between spiritual belief and self
- harmony. Sci. Herit. J., 2, 16 -20 (2018).

Cuiping, Y., P. Xuexia and W. Jiao'ai: Effect of corn straw returned to soil and $\mathrm{N}$ application on growth, water and nitrogen use efficiency of winter wheat [J]. Chin. J. Eco-Agric., 19, 271-275(2011).

Elsayed, J.: Bio-chemical biomarkers in algae Scenedesmus obliquus exposed to heavy metals Cd, Cu and Zn. Acta Chem. Malay., 1, 1620 (2017).

Fahim, N.F. and Z.S. Sathi: Assessment of hepatoprotective activity of roots and barks of Achyranthes aspera in carbon tetrachlorideinduced hepatotoxicity in rats. Malays. J. Halal Res., 1, 23-26 (2018).

Feiyue, L. and W. Jianfei: Estimation of carbon emission from burning and carbon sequestration from biochar producing using crop straw in China [J].Transactions of the Chinese Society of Agricultural Engineering (Transactions of the CSAE), 29, 1-7 (2013).

$\mathrm{Gu}, \mathrm{J}$. and D. Zhang: Analysis on influencing factors of industrial pollution taking Zhejiang Province as an example. Acta Sci. Malays., 2, 1416 (2018).

Guogin, $H .:$ Straw resources and their utilization and development in Southern China. Nat. Res., 5, 64-70 (1997).

Halim, H., R. Abdullah, M.J.M., Nor, H.A. Aziz and N.A. Rahman: Comparison between measured traffic noise in Klang Valley, Malaysia and existing prediction models. Eng. Herit. J., 1, 10-14 (2017).

Hanafiah, M.M., M.Y.M. Ali, N.I.H.A. Aziz and A. John: Biogas production from agro-waste and effluents. Acta Chem. Malay., 1, 13-15 (2017).

Hassan, S.R., N.Q. Zaman and I. Dahlan: Influence of seed loads on start up of modified anaerobic hybrid baffled (MAHB) reactor treating recycled paper wastewater. Eng. Herit. J., 1, 05-09 (2017).

Hong, Z., Q. Mingyan and H. Yong: Analysis on the case of smoke haze [J]. Mon. WeatherRev., 11, 96-100+130 (2008).

Ismail, H. and M.M. Hanafiah: Management of end-of-life electrical and electronic products: The challenges and the potential solutions for management enhancement in developing countries context. Acta Sci. Malays., 1, 05-08 (2017).

Kassim, Z., Z. Ahmad and N. Ismail: Diversity of bivalves in mangrove forest, Tok Bali Kelantan, Malaysia. Sci. Herit. J., 2, 04 -09 (2018).

Kejun, G., Z. Simei and X. Bo: Estimation of total yield and collectable amount of rice straw in Jiangsu Province. J. Ecol. Rural Environ., 28, 32-36(2012).

Lizhen, Y., C. Shengkui and M. Qingwen: Utilization of crop straws and its driving forces in typical rural areas. Chin. J. Eco. Agric., 14, 196198 (2006).

Lu, Z., X. Daxing and W. Hailun: Two-stage cubature kalman filter and its application in water pollution model. Acta Sci. Malays., 2, 09-13 (2018).

Ming, Z., G. Tianpeng and L. Ang: Effects of different combinations of animal manures and chemical fertilizer on yield, nutrient uptake and utilization of spring wheat [J]. J. Triticeae Crops, 2, 216-221 (2014).

National Bureau of Statistics of China: China Statistical Year-book in 2011. Beijing: China Statistics Press (2011).

Qiang, D., W. Honglei and Z. Jihua: A recycling agriculture model based on edible fungi cultivation. J.Anhui. Agri. Sci., 39, 1652516526,16535(2011).

Rehman, R., A. Khan, H. Rashid and A. Nasir: Performance evaluation of fly ash and red brick dust for recovery of chromium from tannery wastewater by adsorption method. Earth Sci. Pak., 1, 19-22 (2017). 
Shaokun, L., W. Keru and F. Jukai: Factors affecting seeding emergence in winter wheat under different tillage patterns with maize stalk mulching returned to the Field [J]. ActaAgronomica Sinica, 3, 463$465+478(2006)$.

Shidan, B.: Soil Agricultural Chemistry Analysis. $3^{\text {rd }}$ Edn., [M]. Beijing: China Agriculture Press, 30-34, 56-58, 81-83, 106-108 (2000).

Shuman, H., J. Hao and N. Zhou: Change of cultivated land and its impact on grain production pattern in Huang-Huai-Hai Plain [J].Trans. Chinese Soc. Agricul. Engin., 30, 268-277 (2014).

Sihai, Z., C. Zhiping and H. Chanjuan: Effect of added straw carbon on soil microbe and protozoa abundance. Chin. J. Eco Agric., 19, 1283-1288 (2011).

Wei, F., Z. Liqun and P. Zhongwei: The economic and environmental analysis of crop residues burning and reutilization in China [J]. Chin. Agri. Sci. Bul., 6, 350-354 (2011).

Weixing. C.: General theory of crop cultivation. $2^{\text {nd }}$ Edn., [M]. Beijing.
Science Press, p. 71 (2011).

Xiaobin, W., C. Dianxiong and Z. Jingqing: Effects of corn stover incorporated in dry farmland on soil fertility [J]. Scientia Agricultura Sinica, 4, 54-61(2000).

Xiaodong, Z., L. Zhan and W. Meng: Wheat optimized fertilization of high yield field with returning whole stalks into the soil in Huang-HuaiHai plain [J]. AnhuiAgricul. Sci., 44, 79-81,106(2016).

Xuecai, Q., Y. Hongli and G. Wangsheng: Effect of crop-residue incorporation on soil $\mathrm{CO}_{2}$ emission and soil microbial biomass. Chinese J. App. Ecol. Mar., 15, 469-472 (2004).

Yasin, H. and M. Usman: Site investigation of open dumping site of municipal solid waste in Faisalabad. Earth Sci. Pak., 1, 23-25 (2017).

Zhigang, D., L. Jianwei and L. Xiaokun: Nutrient release characteristics of different crop straws manure [J]. Transactions of the CSAE, 26, 272-276 (2010). 